\title{
Evaluating the Asymmetric Effects of Production, Interest Rate and Exchange Rate on the Turkish Stock Prices
}

\author{
Üretimin, Faiz Oranın ve Döviz Kurunun Türk Hisse Senedi Fiyatlarına \\ Asimetrik Etkilerinin Incelenmesi
}

\author{
Hüseyin KAYA ${ }^{1}$ \\ Barış SOYBILGEN²
}

\author{
https://orcid.org/0000-0002-2231-9675 \\ https://orcid.org/0000-0003-4906-1878
}

\begin{abstract}
The relationship between stock prices and macro variables has been studied exhaustively in the literature. However, most of the studies assume that this relationship is linear. In this paper, we evaluate the asymmetric effects of production, the interest rate and the exchange rate on Turkish stock prices using non-linear autoregressive distributed lags models. We find that there are both long-run and short-run asymmetric relationships between macro variables and Turkish stock prices. Our results indicate that non-linear models can yield more plausible results compare to linear models.
\end{abstract}

Keywords: Stock Prices, macro variables, interest rate, asymmetry, exchange rate

JEL Codes: G12, C22

\begin{abstract}
ÖZET
Hisse senedi fiyatları ve makro ekonomik değişkenler arasındaki ilişkiyazında etraflıca incelenmiştir. Bununla birlikte çoğu çalışma bu ilişkinin doğrusal olduğunu varsaymıştır. Bu çalışmada üretimin, faiz oranın ve döviz kurunun Türk hisse senedi fiyatlarına asimetrik etkilerini doğrusal olmayan gecikmesi dağıtılmış otoregressif modeller kullanarak değerlendirilmiştir. Çalışmada makro ekonomik değişkenler ile Türk hisse senedi fiyatları arasında hem kısa dönemli hem de uzun dönemli ilişki tespit edilmiştir. Sonuçlar doğrusal olmayan modellerin doğrusal modellere kıyasla daha anlamlı sonuçlar verdiğini göstermiştir.
\end{abstract}

Anahtar Kelimeler: Hisse senedi fiyatları, makro değişkenler, faiz oranı, asimetri, döviz kuru

JEL Kodları: G12, C22

\section{Introduction}

The price of a stock is closely related to firm's fundamentals and future perspectives as well as global and domestic macro factors. For example the Arbitrage Pricing Theory (APT), developed by Ross (1976), states that the return of a security is determined by a number of systematic factors, and the literature shows that macro-economic factors are among them (Chen et. al., 1986; Rapach, 2001; Peiro, 2016).

On the other hand, widely used theoretical stock valuation models such as dividend discount models, free cash flow models or residual income models utilize the present value of forecasted future cash flows

of the company. In a simple and general setup, these valuation models can be represented as:

$P_{t}=\sum_{i=0}^{\infty} \frac{E\left(z_{t+i} \mid \Omega_{\mathrm{t}}\right)}{(1+r)^{i}}$

where $P_{t}$ is the price of a security, $E\left(z_{t+i} \mid \Omega_{\mathrm{t}}\right)$ is expected future dividends (free cash flows or residual income depending on the valuation method) per share conditional on available information at time $t$, and $r$ is the discount rate. Future cash flows of a company in a country are not only depended on firm specific factors but are also depended on macroeconomic conditions suggesting that there is a connection between macroeconomic variables and stock prices. In addition to this, the discount rate is a function of the risk-free rate and 
the risk premium. The monetary policy determines the risk-free rate. The monetary policy is usually specified by an interest rate rule, developed by Taylor (1993) and known as Taylor rule, in which the interest rate (policy rate) is a function of the inflation rate and the output gap. In an emerging market like Turkey, the exchange rate also plays an important role in the monetary policy. For example in the monetary and exchange rate policy document of the Central Bank of Turkey (CBRT), it is clearly stated that "to limit the risks to financial stability, CBRT does not remain unresponsive to an excessive Turkish Lira appreciation or depreciation" (CBRT, 2016, p.2). The second component of the discount rate, the risk premium, is also related to macro-economic variables. Mannonen and Oikarinen (2013) show that monetary policy aggregates, the risk-free interest rate, the term structure of interest rates, inflation, and the state of the business cycle influence the risk premium. Studies in the macro-finance literature also document that the variation of the risk premium is responsive to macro economic factors (Ang and Piazzesi, 2003; Gürkaynak and Wright 2012, Rudebush and Wu, 2008).

While plenty of research investigates the relationship between macroeconomic variables and stock prices/returns (inter alia Bodurtha et al., 1989; Cheung and Ng, 1998; Fraser and Groeneworld, 2006; Groeneworld, 2004; Huang and Guo, 2008; Humpe and Mcmillian, 2009; Kwon and Shin, 1999; Lee, 1992; Louis and Eldomiaty 2010; Maysami and Koh, 2000; Mukherjee and Naka, 1995; Nasseh and Straus, 2000), they assume that this relationship is symmetric. However, recent studies find evidence for the nonlinear relationship between stock returns and macroeconomic variables (Bonga-Bonga and Makkalebule, 2010; Guidolin et al. 2009). For example, Hiemstra and Kramer (1997) provide empirical evidence for the nonlinear causal relationship between macro factors and stock prices. Guidolin and Ono (2006) and Erdoğan and Tirkyaki (2018) document non-linearity in the relationship between stock returns and macroeconomic variables. Guidolin et al. (2009) and Bredin, Hyde and O'Reilly (2008) show that considering the nonlinear effect of macro variables on stock returns improves the returns' predictability. Furthermore, Cuestas and Tang (2015), Bahmani-Oskooee and Saha $(2015,2016,2018)$, and
Cheah et al. (2017) document non-linearity between stock prices and the exchange rate for various countries.

In this study, we aim to contribute to the existing literature by examining asymmetric effects of a set of widely monitored macroeconomic variables on the Turkish stock price index namely: the industrial production index, the interest rate and the exchange rate. We employ the nonlinear autoregressive distributed lags (NARDL) model of Shin et al. (2014) which has become a major workhorse model for the investigation of nonlinear relationships.

The Borsa Istanbul (BIST) is the only stock exchange operating on the Turkish stock market. With the total trading value, reached 13.02 trillion TL in 2016 (4.3 trillion US dollar), the BIST is one of the biggest emerging stock market. As of November 2017, the market capitalization of listed companies is 218.2 billion USD. Currently, the number of traded companies on the BIST is 410 and the BIST has its own indexes, tracking the performance of top 30 (BIST30), top 50 (BIST50), and top 100 (BIST100) companies'. The rest of the paper is organized as follows. Section two provides the estimation methodology and data. Section three reports the empirical results and finally, the last section concludes the paper.

\section{The Methodology and Data}

In order to investigate the effect of output, the interest rate, and the exchange rate on stock prices, we use both linear autoregressive distributed lags (ARDL) models and NARDL models. Studies usually focus on linear/symmetric models to analyze the longrun relationship between macro or financial variables and stock prices. However, the recent literature on nonlinear models shows that omitting nonlinear relationships between variables may cause researchers to derive biased inferences from regressions. Therefore, we adopt NARDL models to analyze the presence of asymmetric relationships between macro variables and stock prices.

First, we use the following linear error-correction model (Model 1) to analyze linear relations:

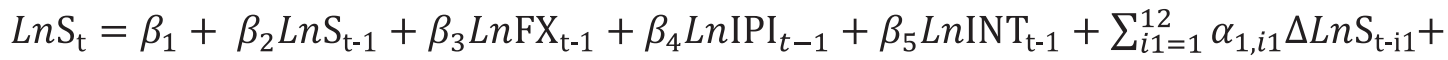

$$
\begin{aligned}
& \sum_{i 2=0}^{12} \alpha_{2, i 2} \Delta L n \mathrm{FX}_{\mathrm{t}-\mathrm{i} 2}+\sum_{i 3=0}^{12} \alpha_{3, i 3} \Delta L n \mathrm{IPI}_{\mathrm{t}-\mathrm{i} 2}+\sum_{i 4=0}^{12} \alpha_{4, i 4} \Delta \operatorname{Ln} \mathrm{INT}_{\mathrm{t}-\mathrm{i} 2}+\varepsilon_{t} \text {, }
\end{aligned}
$$


where $\mathrm{S}_{\mathrm{t}}$ is the Borsa Istanbul (BIST) 100 Index, $\mathrm{FX}_{\mathrm{t}}$ is the Turkish Lira/US Dollar nominal exchange rate, IPI $_{t}$ is the Turkish industrial production index, and $\mathrm{INT}_{t}$ is the 2 year benchmark interest rate ${ }^{2}$ in Turkey. All variables are monthly and the time span is between 2003:M01 and 2017:M06 ${ }^{3}$ and they are obtained from the Turkish Data Monitor (TDM). Figures 1 to 4 show the evaluation of the aforementioned variables over the considered period. Figure 1 and Figure 3 show

\section{Figure 1: BIST100 Index}

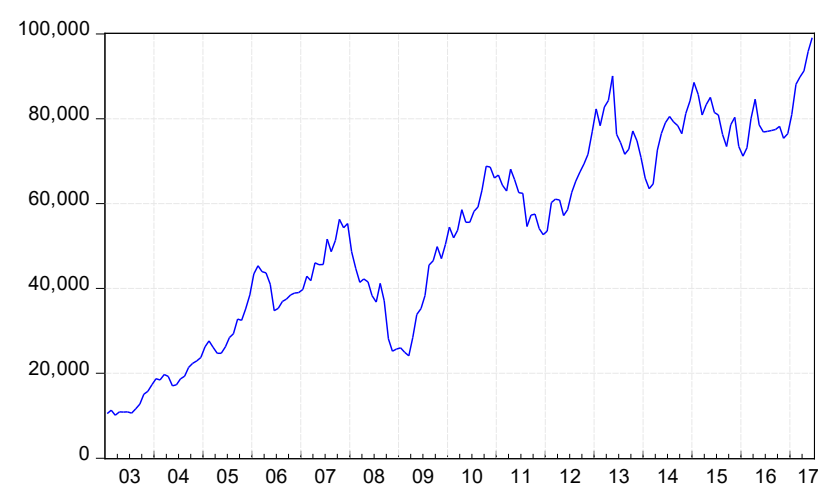

Figure 3: Industrial Production Index

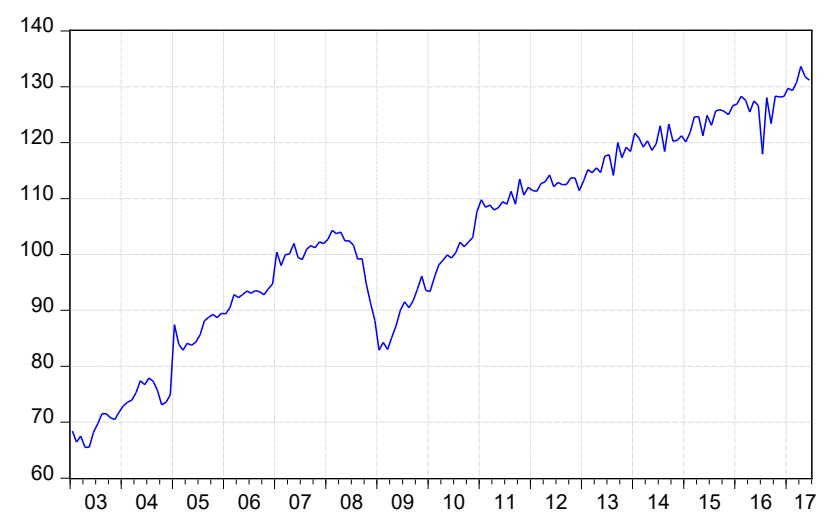

a constant upward trend except the decline in the 2008-2009 crisis. Figure 2 shows that the TL/\$ nominal exchange rate fluctuates around 1.5 until the end of 2010, then the Turkish Lira began to depreciate rapidly. Figure 4 shows that after Turkey adopted implicit inflation targeting, the benchmark interest rate declined to the $10 \%$ from $60 \%$ gradually and stabilized around 10\% from 2010 forward.

Figure 2: TL/\$ nominal exchange rate

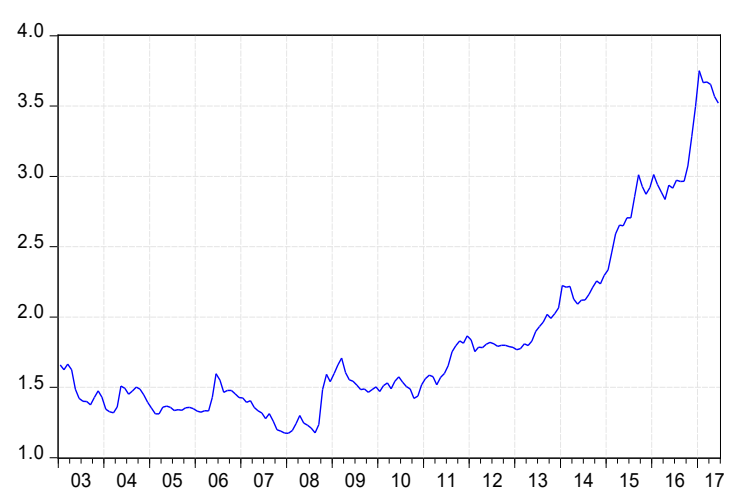

Figure 4: Benchmark interest rate (\%)

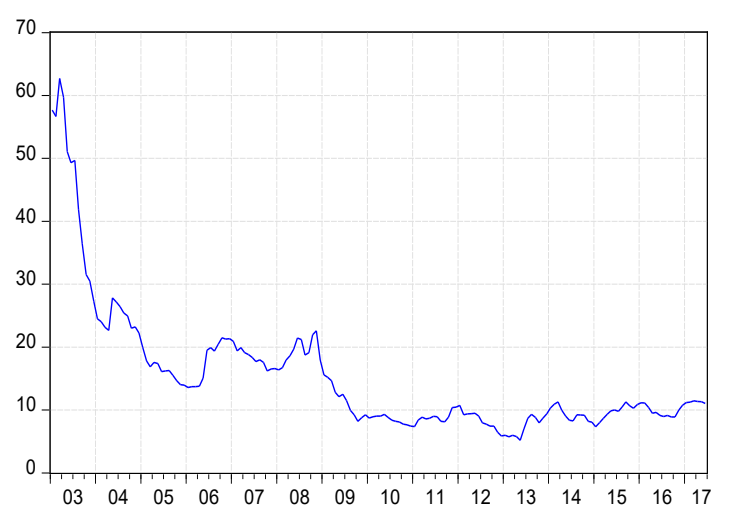

We use a general to specific approach to determine the lag structure. To determine the existence of co-integration relationships between variables, we use the Pesaran et al. (2001) bound test. Once the cointegration relationship is detected, $\frac{\beta_{3}}{\beta_{2}}, \frac{\beta_{4}}{\beta_{2}}$, and $\frac{\beta_{5}}{\beta_{2}}$ are used to measure the long-run elasticities of the BIST 100 index with respect to FX, IPI and INT, respectively. Similarly, coefficients of the first-differenced variables measure the short-run influence of corresponding variables on stock prices.

Secondly, we modify the Equation 1 to analyze asymmetric effects of the exchange rate on stock prices. To accomplish this task, we calculate negative and positive changes in $\Delta L n \mathrm{FX}_{\mathrm{t}}$ following Shin et al. (2014) as below:

$F X-P_{t}=\sum_{j=1}^{t} \max \left(\Delta L n F X_{j}, 0\right)$ and $F X-N_{t}=\sum_{j=1}^{t} \min \left(\Delta L n F X_{j}, 0\right)$, 
where $F X-P_{t}$ and $F X-N_{t}$ are the partial sum of currency appreciations and currency depreciations in $T L / \$$, respectively. Then, our new model (Model
2) which contains asymmetries in $F X_{t}$ is defined as follows:

$$
\begin{aligned}
& L n \mathrm{~S}_{\mathrm{t}}=\beta_{1}+\beta_{2} L n \mathrm{~S}_{\mathrm{t}-1}+\beta_{3} \mathrm{FX}_{-} \mathrm{P}_{\mathrm{t}-1}+\beta_{4} \mathrm{FX}_{-}-\mathrm{N}_{\mathrm{t}-1}+\beta_{5} L n I P I_{t-1}+\beta_{6} L n \mathrm{INT}_{\mathrm{t}-1}+ \\
& \sum_{i 1=1}^{12} \alpha_{1, i 1} \Delta L n \mathrm{~S}_{\mathrm{t}-\mathrm{i} 2}+\sum_{i 2=0}^{12} \alpha_{2, i 2} \Delta \mathrm{FX}-\mathrm{P}_{\mathrm{t}-\mathrm{i} 2}+\sum_{i 3=0}^{12} \alpha_{3, i 3} \Delta \mathrm{FX}-\mathrm{N}_{\mathrm{t}-\mathrm{i} 3}+\sum_{i 4=0}^{12} \alpha_{4, i 4} \Delta L n I P I_{t-i 4}+ \\
& \sum_{i 5=0}^{12} \alpha_{5, i 4} \Delta L n I N T_{t-i 4}+\varepsilon_{t} .
\end{aligned}
$$

Shin et al. (2014) show that the cointegration relationship in the Equation 2 can be tested by the Pesaran et al.'s (2001) bound testing approach. In this setup, the coefficients of $F X-P_{t}$ and $F X-N_{t}$ and their first differences are used to investigate the existence of the asymmetric relationship between the exchange rate and the BIST 100 index in the long-run and the short-run, respectively. More specifically, $\beta_{3} / \beta_{2}$ shows the long-run elasticity of the BIST 100 with respect to the exchange rate appreciation and $\beta_{4} / \beta_{2}$ shows the long-run elasticity with respect to the exchange rate deprecation. So, the presence of the long-run asymmetry can be determined by testing the null hypothesis of $\beta_{3} / \beta_{2}=\beta_{4} / \beta_{2}$ using the Wald test.

Finally, we analyze asymmetric effects of all exogenous variables on stock prices by using the following model (Model 3):

$$
\begin{aligned}
& L n S_{\mathrm{t}}=\beta_{1}+\beta_{2} L n \mathrm{~S}_{\mathrm{t}-1}+\beta_{3} \mathrm{FX}-\mathrm{P}_{\mathrm{t}-1}+\beta_{4} \mathrm{FX}_{\mathrm{N}} \mathrm{N}_{\mathrm{t}-1}+\beta_{5} \mathrm{IPI}_{\mathrm{N}-1}+\beta_{6} \text { IPI-P } \mathrm{P}_{\mathrm{t}-1}+\beta_{7} \text { INT-N }_{t-1}+ \\
& \beta_{8} \text { INT-P }_{t-1}+\sum_{i 1=1}^{12} \alpha_{1, i 1} \Delta L n \mathrm{~S}_{\mathrm{t}-\mathrm{i} 1}+\sum_{i 2=0}^{12} \alpha_{2, i 2} \Delta \mathrm{FX}-\mathrm{P}_{\mathrm{t}-\mathrm{i} 2}+\sum_{i 3=0}^{12} \alpha_{3, i 3} \Delta \mathrm{FX}-\mathrm{N}_{\mathrm{t}-\mathrm{i} 3}+ \\
& \sum_{i 4=0}^{12} \alpha_{4, i 4} \Delta \mathrm{IPI}-\mathrm{P}_{t-i 4}+\sum_{i 5=0}^{12} \alpha_{5, i 5} \Delta \mathrm{IPI}-\mathrm{N}_{t-i 5}+\sum_{i 6=0}^{12} \alpha_{6, i 6} \Delta \mathrm{INT}_{t-i 6}+ \\
& \sum_{i 7=0}^{12} \alpha_{7, i 7} \Delta \mathrm{INT}-\mathrm{P}_{t-i 7}+\sum_{i 8=0}^{12} \alpha_{8, i 8} \Delta \mathrm{INT}_{t-i 8}+\varepsilon_{t} \text {, }
\end{aligned}
$$

where IPI-P ${ }_{t}=\sum_{j=1}^{t} \max \left(\Delta L n \mathrm{IPI}_{j}, 0\right), \mathrm{IPI}_{t}=\sum_{j=1}^{t} \min \left(\Delta L n \mathrm{IPI}_{j}, 0\right)$, INT-P $\mathrm{P}_{t}=$

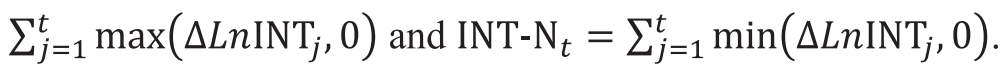

All the models are estimated by the ordinary least squares. In order to arrive the final specification of the NARDL models, we adopt a general-to-specific procedure as we did in the linear model.

\section{Empirical Results}

Equations 4, 5 and 6 show the estimates of Models 1,2 , and 3, respectively. Table 1 presents long-run effects of exogenous variables, diagnostic tests, long-run asymmetry tests, and short-run asymmetry tests.

$$
\begin{aligned}
& \widehat{L n \mathrm{~S}_{\mathrm{t}}}=0.60-0.12 * L n \mathrm{~S}_{\mathrm{t}-1}+0.04 * L n \mathrm{FX}_{\mathrm{t}-1}+0.20 * L n \mathrm{IPI}_{t-1}-0.072 * L n \mathrm{Int}_{\mathrm{t}-1}+0.13 * \Delta L n \mathrm{~S}_{\mathrm{t}-11}+0.99 * \\
& \Delta L n \mathrm{~S}_{\mathrm{t}-5}+0.12 * \Delta L n \mathrm{~S}_{\mathrm{t}-2}+0.09 * \Delta L n \mathrm{~S}_{\mathrm{t}-9}-0.99 * \Delta L n \mathrm{FX}_{\mathrm{t}}-0.22 * \Delta L n \mathrm{FX}_{\mathrm{t}-12}+0.21 * \Delta L n \mathrm{IPI}_{\mathrm{t}-2}-0.36 * \\
& \Delta L n \mathrm{INT}_{\mathrm{t}}
\end{aligned}
$$

$$
\begin{aligned}
& \widehat{\operatorname{LnS}}=0.30-0.07 * \operatorname{LnS} \mathrm{S}_{\mathrm{t}-1}+0.06 * \mathrm{FX}_{\mathrm{t}} \mathrm{P}_{\mathrm{t}-1}+0.15 * \mathrm{FX}-\mathrm{N}_{\mathrm{t}-1}+0.19 * \operatorname{LnIPI}_{t-1}-0.12 * \operatorname{LnInt}_{\mathrm{t}-1}-0.14 * \\
& \Delta L n \mathrm{~S}_{\mathrm{t}-7}-0.13 * \Delta L n \mathrm{~S}_{\mathrm{t}-6}-0.10 * \Delta L n \mathrm{~S}_{\mathrm{t}-11}-0.56 * \Delta L n \mathrm{FX}-\mathrm{N}_{\mathrm{t}}-0.30 * \Delta L n \mathrm{FX}-\mathrm{P}_{\mathrm{t}}-0.24 * \Delta L n \mathrm{FX}-\mathrm{N}_{\mathrm{t}-8}-0.42 *(5) \\
& \Delta \operatorname{Ln} \mathrm{INT}_{\mathrm{t}}-0.15 * \Delta \operatorname{LnINT}_{\mathrm{t}-6} \\
& \widehat{\operatorname{LnS}}=1.51-0.09 * \operatorname{LnS} \mathrm{S}_{\mathrm{t}-1}-0.07 * \mathrm{FX}-\mathrm{P}_{\mathrm{t}-1}+0.08 * \beta_{4} \mathrm{FX}_{\mathrm{t}} \mathrm{N}_{\mathrm{t}-1}-0.01 * \text { IPI }_{\mathrm{N}} \mathrm{N}_{t-1}+0.001 * \text { IPI-P } \mathrm{P}_{\mathrm{t}-1}-0.002 * \\
& \text { Int- } \mathrm{N}_{t-1}-0.005 * \text { Int }-\mathrm{P}_{t-1}+0.15 * \Delta L n \mathrm{~S}_{\mathrm{t}-7}-0.83 * \Delta L n \mathrm{FX}-\mathrm{N}_{\mathrm{t}}-0.45 * \Delta L n \mathrm{FX}-\mathrm{P}_{\mathrm{t}}-0.21 * \Delta L n F X-\mathrm{N}_{\mathrm{t}-8}-0.03 *(6) \\
& \Delta L n I N T-\mathrm{P}_{\mathrm{t}}-0.01 * \Delta L n I N T-\mathrm{P}_{\mathrm{t}-11}-0.01 * \Delta L n \text { INT }-\mathrm{P}_{\mathrm{t}-6}-0.01 * \Delta L n \text { INT- } \mathrm{N}_{\mathrm{t}}+0.01 * \Delta L n \text { INT- } \mathrm{N}_{\mathrm{t}-6}-0.004 *
\end{aligned}
$$

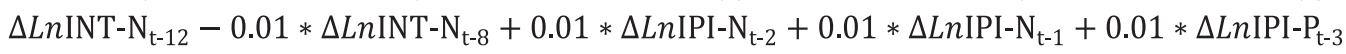


Table 1: Estimation Results of Linear and Nonlinear ARDL Models

\begin{tabular}{ccc}
\hline ARDL & NARDL & NARDL \\
Model 1 & Model 2 & Model 3 \\
\hline
\end{tabular}

Panel A: Long-run

Relations

$\begin{array}{lccc}\text { FX } & 0.32^{* *} & --- & --- \\ \text { IPI } & 1.58^{* *} & 2.68^{*} & --- \\ \text { INT } & -0.58^{* * *} & -1.75^{* * *} & --- \\ \text { FX-P } & --- & 0.86^{* * *} & -0.80^{* * *} \\ \text { FX-N } & --- & 2.19^{* * *} & 0.83^{*} \\ \text { IPI-P } & --- & --- & 0.01 \\ \text { IPI-N } & --- & --- & -0.05^{* * *} \\ \text { INT-P } & --- & --- & -0.05^{* *} \\ \text { INT-N } & --- & --- & -0.02^{* *}\end{array}$

Panel B: Diagnostics

$\begin{array}{lccc}\text { Bounds Test } & 8.61^{* * *} & 8.33^{* * *} & 7.47^{* * *} \\ \text { LM Test } & 17.63 & 13.07 & 13.81 \\ \text { ARCH Test } & 6.31 & 8.98 & 12.08 \\ \text { CUSUM } & \text { Stable } & \text { Stable } & \text { Stable } \\ \text { CUSUMSQ } & \text { Stable } & \text { Stable } & \text { Stable }\end{array}$

Panel C: Long-run Asymmetry Tests

$\begin{array}{lcc}\text { FX } & 4.05^{* *} & 4.95^{* *} \\ \text { IPI } & -- & 9.25^{* * *} \\ \text { INT } & --- & 2.31\end{array}$

Panel D: Short-run Asymmetry Tests

$\begin{array}{lcc}\text { FX } & 4.62^{* *} & 6.17^{* *} \\ \text { IPI } & --- & 11.43^{* * *} \\ \text { INT } & --- & 20.41^{* * *}\end{array}$

According to diagnostic tests, all models seem to be specified correctly. They show no sign of serial correlation and heteroscedasticity. CUSUM tests and CUSUM of squares tests show no sign of parameter instability. Bounds tests show that there is a cointegration relationship in all equations. Therefore, we can begin analyzing equations. In the first model, the IPI affects stock prices positively as expected both in the long-run and the short-run. A $1 \%$ increase in the IPI causes a $1.58 \%$ increase in the stock price in the longrun. Furthermore in line with the literature, an increase in the interest rate reduces stock prices both in the long-run and the short-run. A depreciation in the Tur- kish lira affects stock prices negatively in the short-run but in contrast to the general logic, a depreciation in the Turkish lira seems to affect stock prices positively in the long-run. The use of asymmetric relations may improve the results.

In the equation 2, we model the FX asymmetrically. A depreciation in the Turkish Lira still causes stock prices to increase in the long-run. However in line with the expectations, an appreciation in the Turkish Lira also raises stock prices in the long-run and the sign of FX-N is much higher than FX-P. In the short-run, both FX-P and FX-N cause stock prices to decline, and like in the long-run, the sign of FX-N is much higher than FX-P. The Wald test rejects the long-run and the shortrun symmetry with respect to FX, indicating that the effects of depreciation and appreciation in exchange rate on stock prices are different. These results give us more insight than linear ARDLs. Furthermore, signs of the IPI coefficient and the INT coefficient are in line with the expectations.

In the equation 3, we model all macro economic variables asymmetrically. This time, signs of the long-run coefficients of FX-P and FX-N are found to be consistent with the expectations. A depreciation in the Turkish Lira causes stock prices to decline and an appreciation in Turkish Lira raises them. However in the short-run, both FX-P and FX-N still lead to a decline in stock prices. Long-run influence of IPI-P and IPI-N are also in line with expectations. On the other hand, both IPI-P and IPI-N cause stock prices to increase in the short-run. Asymmetry tests for long-run and short-run for both the IPI and the FX suggest that they are better be modelled as asymmetrical. On the other hand, long-run asymmetry test for INT indicates that effects of an increase in interest rate and a decrease in interest rate on stock prices are not different in magnitude. However, those affects are not same in the short-run. Both INT-P and INT-N have negative signs both in the long-run and the short-run.

\section{Conclusion}

In this study, we use both symmetric and asymmetric ARDL models to analyze both long-run and short-run effects of production, the interest rate and the exchange rate on Turkish stock prices. We find that both the exchange rate and the industrial production index have asymmetric effects on Turkish stock prices both in the long-run and the short-run. However, we fail to show that the interest rate has asymmetric long-run effects on stock prices but we show that the 
interest rate has asymmetric effect in the short-run. Our results show that modelling the exchange rate and the industrial production index symmetrically causes us to derive wrong inferences. Thus, NARDL

\section{End Notes}

1. http://www.borsaistanbul.com/en/data/data/consolidated-data

2. The 2 year benchmark interest rate is one of the most closely watched interest rate in Turkey. As Turkey was a high inflation country in the 90 s and in the early 2000s, bonds with longer maturities such as 5 years and 10 years was not available in Turkey for the most of 2000s. Interest rates with shorter time span are usally more volatile compared to the 2 year benchmark interest rate. Therefore, we use the 2 year benchmark interest rate in our study.

3. We use the time span after 2003 to estimate the model because Turkey adopted implicit inflation targeting after 2002 and this reduced the inflation rate from $60 \%$ to single digit numbers in a few year. Furthermore, a series of economic reforms implemented by Justice and the Development Party after 2003 alter the structure of the economy greatly. emerges as a more suitable model than linear models for investigating the long-run relationship between macro variables and stock prices. 


\section{References}

Ang, A., \& Piazzesi, M. (2003) "A no-arbitrage vector autoregression of term structure dynamics with macroeconomic and latent variables" Journal of Monetary Economics, 50(4), 745-787.

Bahmani-Oskooee, M., \& Saha, S. (2015) “On the relation between stock prices and exchange rates: a review article" Journal of Economic Studies, 42(4), 707-732.

Bahmani-Oskooee, M., \& Saha, S. (2016) “Do exchange rate changes have symmetric or asymmetric effects on stock prices?" Global Finance Journal, 31, 57-72.

Bahmani-Oskooee, M., \& Saha, S. (2018) "On the relation between exchange rates and stock prices: a non-linear ARDL approach and asymmetry analysis" Journal of Economics and Finance, 42(1), 112-137.

Bodurtha Jr, J. N., Cho, D. C., \& Senbet, L. W. (1989) “Economic forces and the stock market: An international perspective" Global Finance Journal, 1(1), 21-46.

Bonga-Bonga, L., \& Makakabule, M. (2010) "Modeling stock returns in the South African stock exchange: A nonlinear approach" European Journal of Economics, Finance and Administrative Sciences, 19, 168-177.

Bredin, D., Hyde, S. \& O'Reilly, G. (2008) "Regime changes in the relationship between stock returns and the macroeconomy" British Accounting Association Annual Conference, 1-25.

Cheah, S. P., Yiew, T. H., \& Ng, C. F. (2017) "A nonlinear ARDL analysis on the relation between stock price and exchange rate in Malaysia" Economics Bulletin, 37(1), 336-346.

Chen, N. F., Roll, R., \& Ross, S. A. (1986) "Economic forces and the stock market" Journal of Business, 59 (3), 383-403.

Cheung, Y. W., \& Ng, L. K. (1998) "International evidence on the stock market and aggregate economic activity" Journal of Empirical Finance, 5(3), 281-296.

Cuestas, J. C., \& Tang, B. (2015) "Asymmetric exchange rate exposure of stock returns: Empirical evidence from Chinese Industries" The Sheffield Economic Research Paper Series No. 2015021.

Erdoğan, L., \& Tiryaki, A. (2018) "Asymmetric Effects of Macroeconomic shocks on the Stock Returns of the G-7 Countries: The Evidence from the NARDL Approach" Journal of Current Researches on Business and Economics, 8(1), 119-146.

Fraser, P., \& Groenewold, N. (2006) "US share prices and real supply and demand shocks" The Quarterly Review of Economics and Finance, 46(1), 149-167.
Groenewold, N. (2004) "Fundamental share prices and aggregate real output" Applied Financial Economics, 14(9), 651-661.

Guidolin, M., Hyde, S., McMillan, D., \& Ono, S. (2009) "Non-linear predictability in stock and bond returns: When and where is it exploitable?" International Journal of Forecasting, 25(2), 373-399.

Guidolin, M., \& Ono, S. (2006) "Are the dynamic linkages between the macroeconomy and asset prices time-varying?" Journal of Economics and Business, 58(5), 480-518.

Gürkaynak, R. S., \& Wright, J. H. (2012) "Macroeconomics and the term structure" Journal of Economic Literature, 50(2), 331-367.

Hiemstra, C., \& Kramer, C. (1997) "Nonlinearity and endogeneity in macro-asset pricing" Studies in Nonlinear Dynamics \& Econometrics, 2(3), 61-76.

Huang, Y., \& Guo, F. (2008) "Macro shocks and the Japanese stock market" Applied Financial Economics, 18(17), 1391-1400.

Humpe, A., \& Macmillan, P. (2009) “Can macroeconomic variables explain long-term stock market movements? A comparison of the US and Japan" Applied Financial Economics, 19(2), 111-119.

Kwon, C. S., \& Shin, T. S. (1999) "Cointegration and causality between macroeconomic variables and stock market returns" Global Finance Journal, 10(1), 71-81.

Lee, B. S. (1992) "Causal relations among stock returns, interest rates, real activity, and inflation" The Journal of Finance, 47(4), 1591-1603.

Louis, R. J., \& Eldomiaty, T. (2010) "How do stock prices respond to fundamental shocks in the case of the United States? Evidence from NASDAQ and DJIA" The Quarterly Review of Economics and Finance, 50(3), 310-322.

Mannonen, P., \& Oikarinen, E. (2013) "Risk premium, macroeconomic shocks, and information technology: an empirical analysis" International Review of Applied Economics, 27(5), 695-705.

Maysami, R. C., \& Koh, T. S. (2000) "A vector error correction model of the Singapore stock market" International Review of Economics \& Finance, 9(1), 79-96.

Mukherjee, T. K., \& Naka, A. (1995) “Dynamic relations between macroeconomic variables and the Japanese stock market: an application of a vector error correction model" Journal of Financial Research, 18(2), 223-237. 
Nasseh, A., \& Strauss, J. (2000) "Stock prices and domestic and international macroeconomic activity: a cointegration approach" The Quarterly Review of Economics and Finance, 40(2), 229-245.

Peiró, A. (2016) "Stock prices and macroeconomic factors: Some European evidence" International Review of Economics \& Finance, 41, 287-294.

Pesaran, M. H., Shin, Y., \& Smith, R. J. (2001) "Bounds testing approaches to the analysis of level relationships" Journal of applied econometrics, 16(3), 289-326.

Rapach, D. E. (2001) "Macro shocks and real stock prices" Journal of Economics and Business, 53(1), 5-26.
Ross, S. A. (1976) "The arbitrage theory of capital asset pricing" Journal of Economic Theory, 13(3), 341-360.

Shin, Y., Yu, B., \& Greenwood-Nimmo, M. (2014) “Modelling asymmetric cointegration and dynamic multipliers in a nonlinear ARDL framework" In Festschrift in Honor of Peter Schmidt (pp. 281-314). Springer New York.

Taylor, J. B. (1993) "Discretion versus policy rules in practice" Carnegie-Rochester Conference Series on Public Policy, 39, 195-214.

CBRT. (2016) "Monetary and Exchange Rate Policy for 2017" Available from https://goo.gl/rSSBbi 